\title{
視床下部性肥満ラットの膵ラ氏島の組織学的検討
}

\author{
徳島大学医学部第 2 内科学教室 \\ (主任：森 博愛教授) \\ 和 泉 英 彦
}

Histological Study of Pancreatic Islets in Hypothalamic Obese Rats

\section{Hidehiko IZUMI}

\author{
The Second Department of Internal Medicine, School of Medicine, \\ Tokushima University, \\ Tokushima, Japan \\ (Director: Prof. Hiroyoshi Mori)
}

It has been considered that hyperinsulinemia is one of the important factors in the development of obesity. With the purpose of investigating the mechanisms of hyperinsulinemia in obese rats induced by hypothalamic lesions (HTL), the time-caused changes in body weight, blood glucose and plasma immunoreactive insulin (IRI) levels in addition to histological changes in the pancreatic islet were studied.

The following results were obtained.

1. The development of obesity, a rise of plasma IRI level and an enlargement of pancreatic islets were found in HTL rats. The enlargement of pancreatic islets was directly proportional to body weight, index of obesity and plasma IRI level.

2. The B cells of the pancreatic islets of HTL rats revealed well-developed Golgi apparatus and rough endoplasmic reticulum, and numerous degranulated and pale secretory granules.

3. A number of mixed cells were shown in the periphery of the pancreatic islets of HTL rats.

4. Emiocytotic phenomena of the granular discharge were encountered frequently in the $B$ cells of the pancreatic islets of HTL rats.

These histological findings of the B cells in HTL rats well reflected hypersecretion of insulin in this type of obesity.

\section{緒言}

肥満の発生には多くの要素が関与すると考えられているが、いまだその成因は充分に解明されていない. 肥満発生への間脳の関与については Hetherington, Ranson ${ }^{(16)}$ が実験的に視床下部性肥満ラットの作製に成 功して以来, 多数の研究が行なわれ, ${ }^{(1)(3)(8)}$ 視床下部外側部に摂食中枢が, 腹内側部に満腹中枢が存在し ${ }^{(33)} こ$ 
れらの部位の障害によって肥満が生じることが明らかになってきた。(4)(45)

著者の教室では，これまで視床下部破壊（hypothalamic lesion, HTL) ラットを用いて肥満の成因につい ての研究を行ない, 次のような成績を得ている. HTL 後早期より血漿 immunoreactive insulin (IRI) 值が 著しく上昇する. ${ }^{\left({ }^{(6)}\right)} \mathrm{H}$ T Lラットではリノール酸の減少，パルミチン酸の増加が認められ，正常ラットにイ ンスリンを投与しても，これと同様の変化を起こす。 ${ }^{(24)}$ また, あらかじめ下垂体を摘除しておいても, ${ }^{(12)}$ tube fedによって対照と同一の食事を与えても， ${ }^{(39)} \mathrm{H}$ T L ラットでは肥満や高インスリン血症が発生する.

以上の成績から, H T Lラットの肥満発生の成因として過食, 下垂体機能の障害以外に高インスリン血症 が重要な役割をはたしていることが推察された。

そこで著者はH T Lラットの肥満発生と高インスリン血症の関係を検討するために, 膵ラ氏島, 特にB 細 胞の変化を光顕的および電顕的に検索し, さらに血漿 I R I 值との対比についても検討した.

\section{実験材料および方法}

\section{I） H T Lラットの作製}

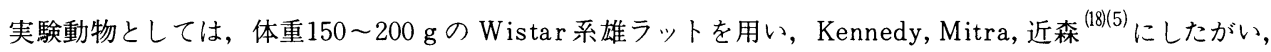
pentobarbital sodium 麻配後視床下部腹内側核を中心とする部位を, 定位脳固定装置を用い, D C $2 \mathrm{~m} \mathrm{A,}$ 15秒で電気凝固的に両側性に破壊した。術後は感染予防のため抗生物質を投与した，对照としては同領域に 電極針を刺入するだけで電流を流さないラットを用い, sham-HTLラット群とした。

実験動物は室温 $22^{\circ} \mathrm{C}$ に保ち, 水や飼料（オリエンタル固形飼料）は自由に与え, 個々のケージに入れて飼 育した。体重と食事搨取量を毎週 2 回測定し, 肥満の判定には体重と Lee's index $(\sqrt[3]{\mathrm{W} / \mathrm{L}}: \mathrm{W}$ 体重, L 身 長）を用いた。屠殺後は副蔁丸脂肪重量や体脂肪量も測定した。

2 ) 生化学的測定法

これらのラットからの採血は, 術後 $1 ， 5 ， 10,15$ 週目に, すべて 4 時間絶食後, 断頭して行なった。血 糖は glucose oxidase法, ${ }^{(20)}$ 血漿 I R I はdouble antibody methodによる radioimmunoassay で測定し, porcine standardに対する $\mu \mathrm{U} / \mathrm{ml}$ で表現した. ${ }^{(32)}$

\section{3 ) 組織学的検索法}

\section{(1) 光学顕微鏡的方法}

術後 $1,5,10,15$ 週で 4 時間絶食後, 断頭し直ちに開腹し, 䐙尾部の小組織を摘出した. 䐙組織は Bouin 氏液で固定，パラフィン包埋し，切片は200 $\mu$ 間隔で連続的に切裁し, aldehyde-fuchsin-hematoxylin 染色 ${ }^{(10)}$ を行なった。そして, 光学顕微鏡下に観察し, ラ氏島約50個を無差別に選び同じラ氏島を測定しない ように micrometer を用いて島の長径と短径を測定し，ほぼ楕円形の面積としてラ氏島の面積を算出した。

脳の障害部位を確認するため, 脳をホルマリン固定後, 前頭断切片を作製し, $\mathrm{H}-\mathrm{E}$ 染色を行なった. 障 害部位が腹内側部以外の場合は実験対象から除外した。

(2) 電子顕微鏡的方法

光顕標本作製と同時に摘出した膵組織の一部は $5 \%$ glutaraldehyde と Os O4で二重固定し, eponに包 埋, ${ }^{(29)}$ 超薄切片は酢酸ウラニールと硝酸鉛で二重染色を施し, 電顕観察に供した。

\section{実 験 成 績}

\section{1) H T Lラットの体重および肥満度}

Fig. 1 にH T L群と対照群の平均体重の経時的変化を示した.H T L 群では H T L 後早期より対照群に比 べて体重の増加がみられ, 次第にその差が開き, 15週目のH T L 群では661 $\pm 15.1 \mathrm{~g}$ と対照群の $503 \pm 37.0 \mathrm{~g}$ に比べて有意に増加した。 $(\mathrm{P}<0.005)$ これ Lee’s indexで表現すると，15週目ではH T L 群0.325士0.

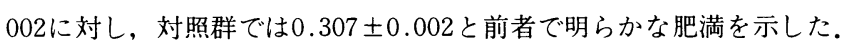




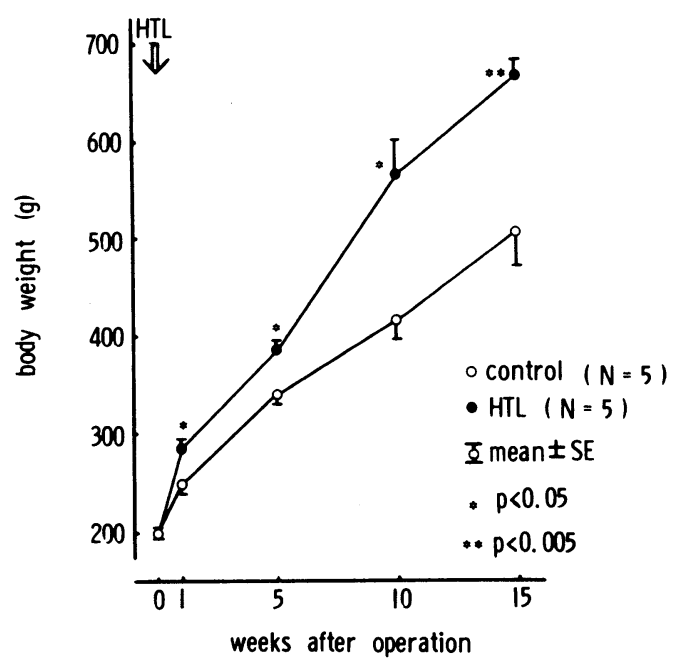

Fig. 1. Weight gain of the rats with or without hypothalamic lesions. HTL: hypothalamic lesion
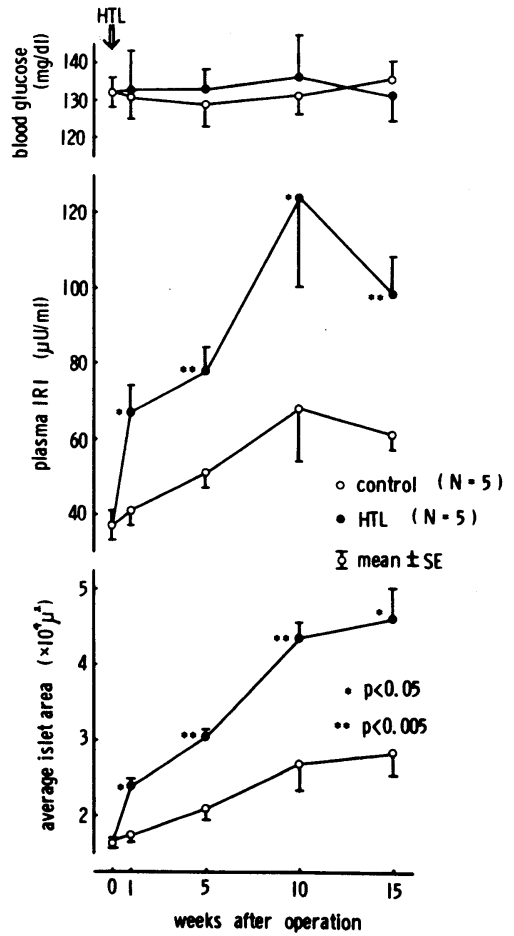

Fig. 2. Blood glucose, plasma IRI and average islet area in the rats with or without hypothalamic lesions.

IRI: immunoreactive insulin

HTL: hypothalamic lesion 


\section{2) H T Lラットの血糖おょび血漿 I R I}

Fig. 2 に H T L群と対照群の血糖および血漿 I R I の経時的変動を示した. 血糖はいずれの時期において も H T L 群と対照群の間に有意の差がみられず，また，両群共に時期による変動はほとんどみられなかった。 しかし血漿 I R I 值は, 1 週目では対照群の $41 \pm 4.6 \mu \mathrm{U} / \mathrm{ml}$ に対し, H T L群では $67 \pm 7.8 \mu \mathrm{U} / \mathrm{ml}$ と術後早期 から有意に高值を示した $(\mathrm{P}<0.05)$. 10週目にはさらにこの差が大となり，対照群の $68 \pm 14.5 \mu \mathrm{U} / \mathrm{ml}$ に対し，

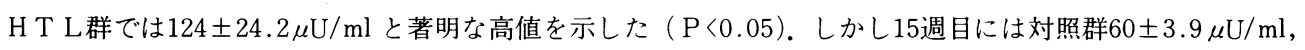
H T L 群 $98 \pm 9.3 \mu \mathrm{U} / \mathrm{ml}$ となり（P<0.005）．ともに10週目に比べてや，低值を示した.

\section{3 ） H T Lラットの膵ラ氏島面積}

Fig. 2 最下段にH T L 群と対照群の各時期における荤ラ氏島面積の平均值を示した. H T L 群のラ氏島面 積は, 前記の血漿 I R I 值の増加にほぼ平行して拡大し, 15週目の H T L群では $4.619 \pm 0.946 \times 10^{4} \mu^{2}$ と対 照群の $2.869 \pm 0.321 \times 10^{4} \mu^{2}$ に比べて著明な拡大を示した $(\mathrm{P}<0.05)$.

つぎに, ラ氏島面積と体重, Lee’s index および血漿 I R I との相関につき検討した. ラ氏島面積と体重 との間には $\gamma=0.796(\mathrm{P}<0.001)$ (Fig. 3), Lee’s index との間には $\gamma=0.695(\mathrm{P}<0.001)$ (Fig. 4 ), 血漿 I R I との間には $\gamma=0.679(\mathrm{P}<0.001)$ (Fig. 5 ) と各々有意の正相関を認めた.

4 ) H T Lラットの膵ラ氏島の組織学的所見

\section{(1) 光学顕微鏡所見}

Fig. 6 右は10週目のH T Lラットの平均的ラ氏島を示した. H T L ラットのラ氏島は同倍率でとった同時 期の対照ラットの平均的ラ氏島（Fig. 6 左）に比べて著明に拡大していた．ラ氏島中央部を占めるB 細胞の 数は増加し, その顆粒は減少していた。しかし, ラ氏島周辺にみられる Aおよび D 細胞には著明な変化はみ られなかった。 また, 細胞の面積と細胞数を各ラ氏島について, 光顕でとった写真を拡大して計測した. 細 胞の面積は H T L と対照ラットの間に著明な差を認めなかったが，細胞の数は H T Lラットの方が対照ラッ トより著明に多かった。また，H T Lラットのラ氏島では対照ラットに比べて線維組織が多い傾向がみられ た。

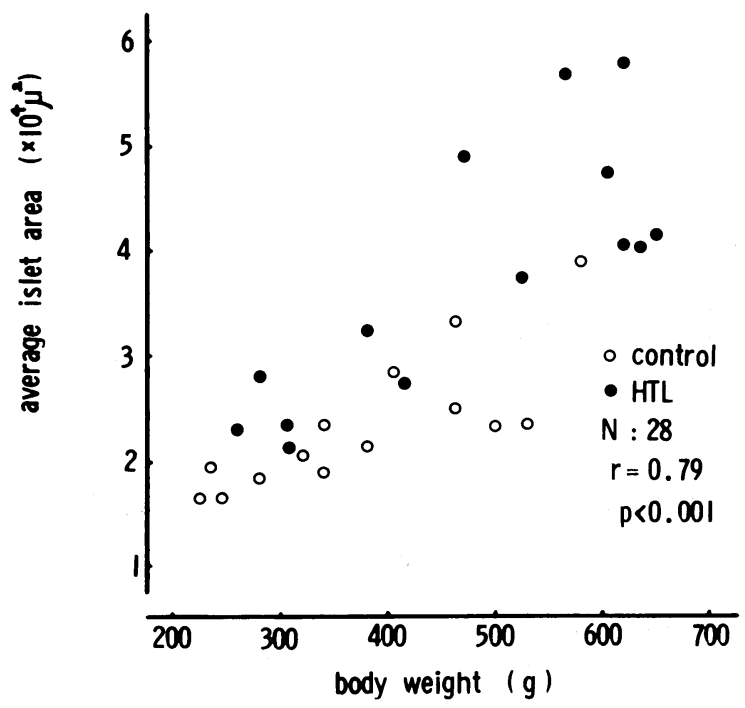

Fig. 3. Correlation between average islet area and body weight in the rats with or without hypothalamic lesions. HTL: hypothalamic lesion 


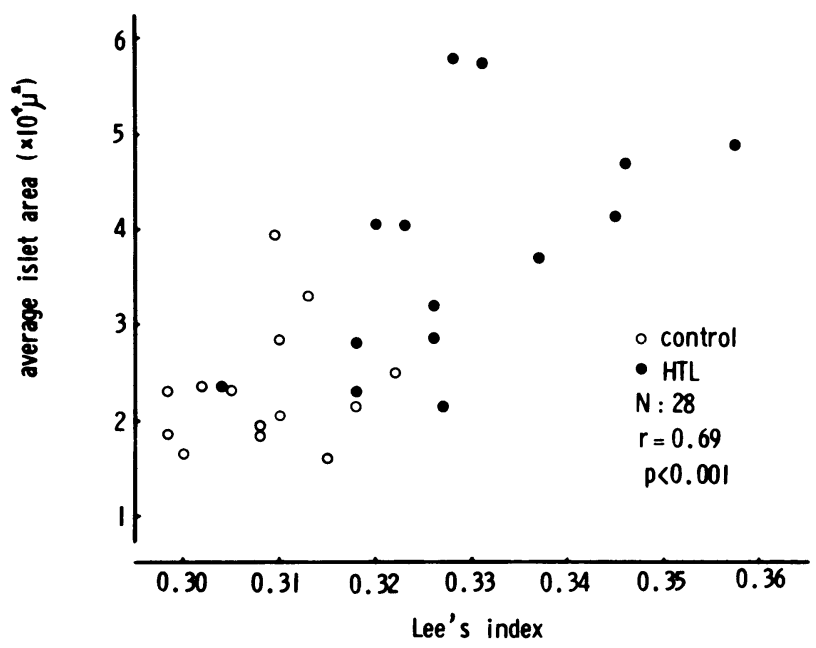

Fig. 4. Correlation between average islet area and Lee's index in the rats with or without hypothalamic lesions. HTL: hypothalamic lesion

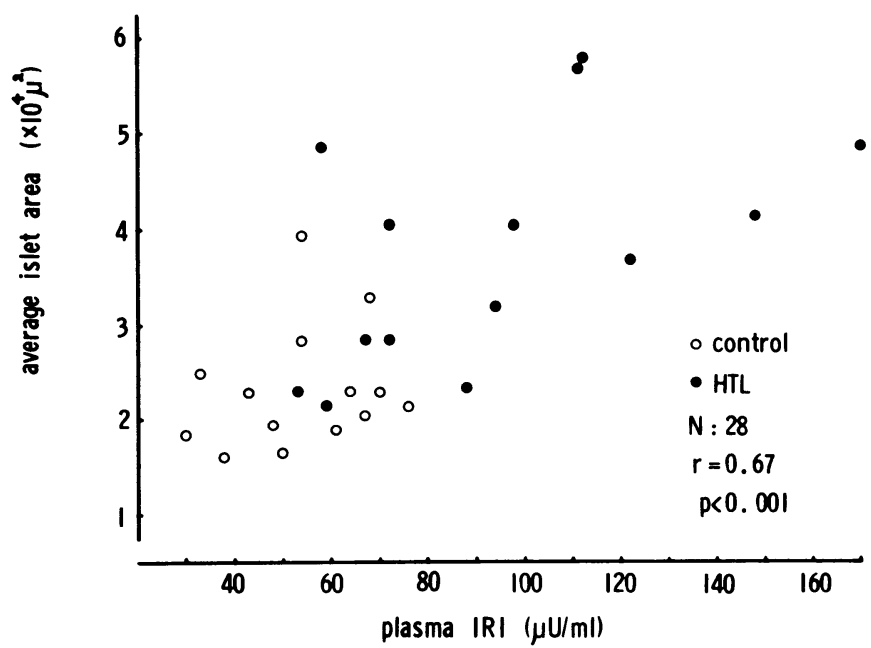

Fig. 5. Correlation between average islet area and plasma IRI in the rats with or without hypothalamic lesions.

IRI: immunoreactive insulin

HTL: hypothalamic lesion 

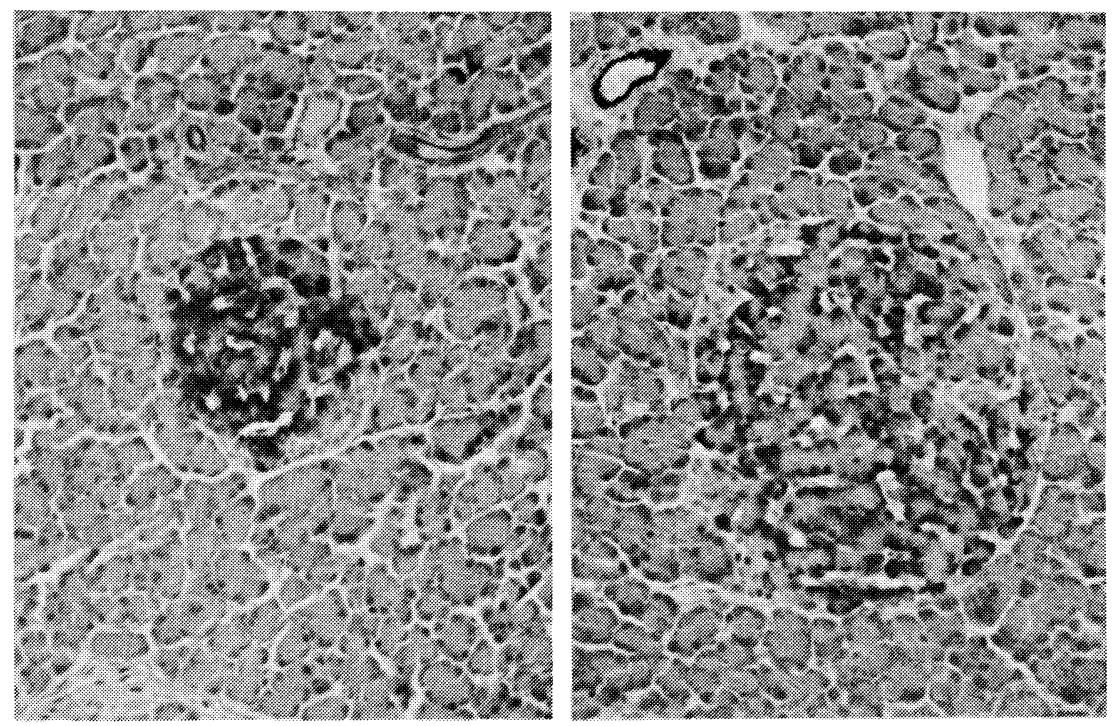

Fig. 6. Light micrograph of the pancreatic islet of the control rat (left) and that of the hypothalamic lesion rat (right) at 10 weeks after the operation. $(\times 400)$

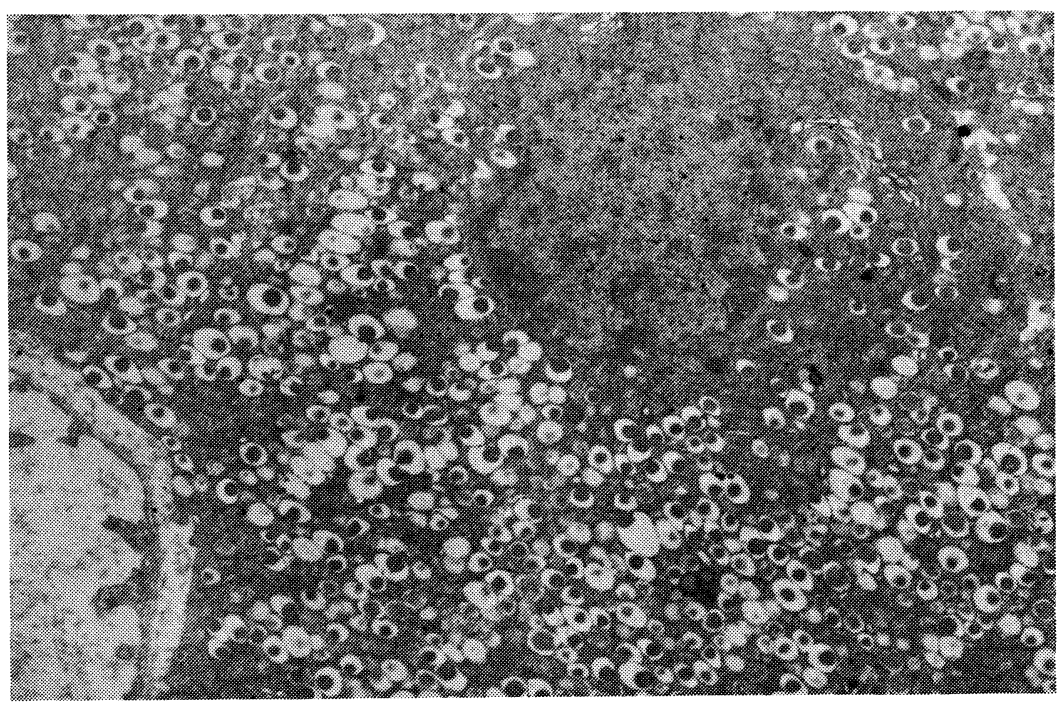

Fig. 7. Electron micrograph of pancreatic B cells of the control rat at 10 weeks after the sham-operation. $(\times 6000)$

\section{(2) 電子顕微鏡所見}

まず血漿 I R I 值が頂値を示したH T L後10週目の脺ラ氏島 B 細胞について観察したＨＴＬ後10週にお ける対照ラットをFig. 7 に示した。細胞質全体に $\beta$ 顆粒（ $\beta$-granule）が多数分布していた. 顆粒は膜につ つまれ, この顆粒の電子密度は種々で, 電子密度の高いものでは顆粒がや、小さく, 低いものは大きい傾向 が認められた。一般には電子密度の高い顆粒が低い顆粒に比べて多く認められた。 
細胞の Golgi 装置は主に核の周囲に存在することが多く, 小胞と扁平な襄とからなる，小胞の一部には電 子密度の比較的高い物質が含まれることがあり，これが pregranule であるかもしれない，粗面小胞体は細 胞全体に分布し, 膜は時に平行に配列し, 内腔にや、電子密度の高い物質を含んでいた，系粒体 (mitochondria）は比較的小数で細胞膜の直下に認められることが多かった. cristae は系粒体の長軸に直角に並び, 糸粒体顆粒はほとんど認められなかった。

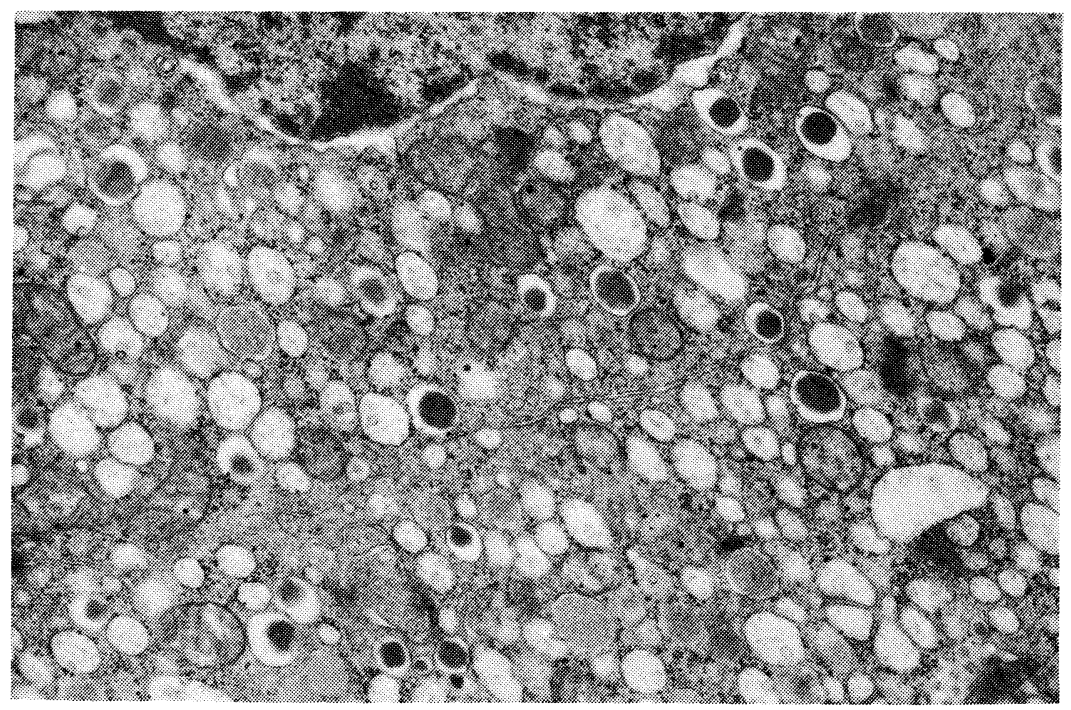

Fig. 8. Electron micrograph of pancreatic B cells of hypothalamic lesion rat at 10 weeks after the operation. Degranulation of B cell is remarkable and rough endoplasmic reticulum is well developed. $(\times 12000)$

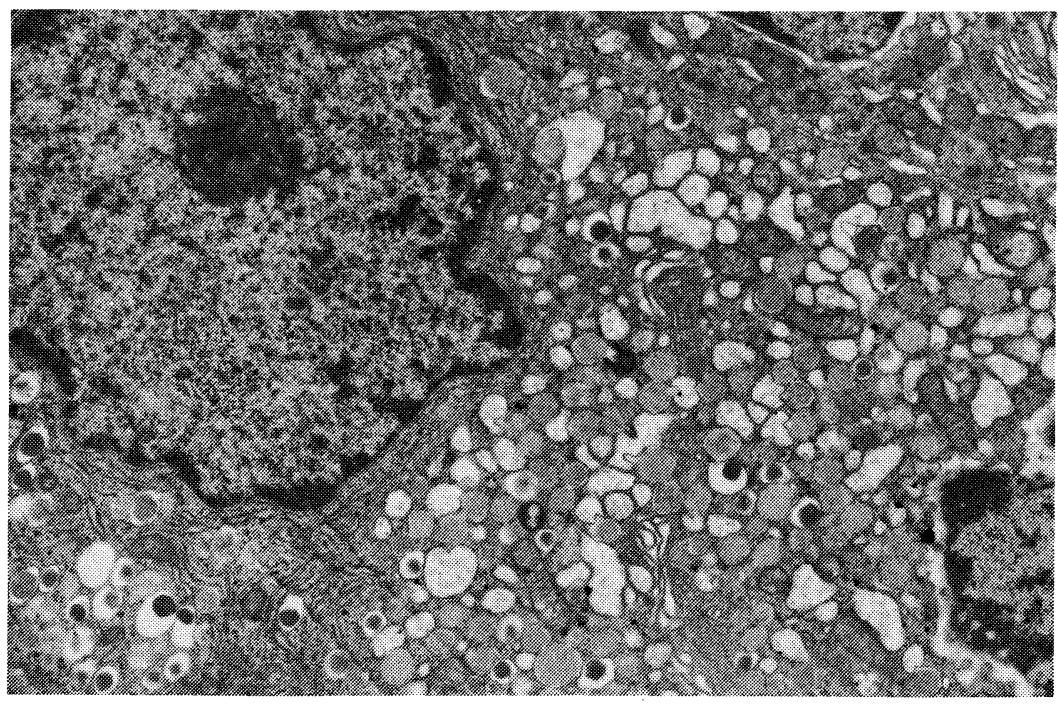

Fig. 9. Electron micrograph of pancreatic B cells of hypothalamic lesion rat at 10 weeks after the operation. Pale granules are numerous and these granules are fused each other. (X12000) 


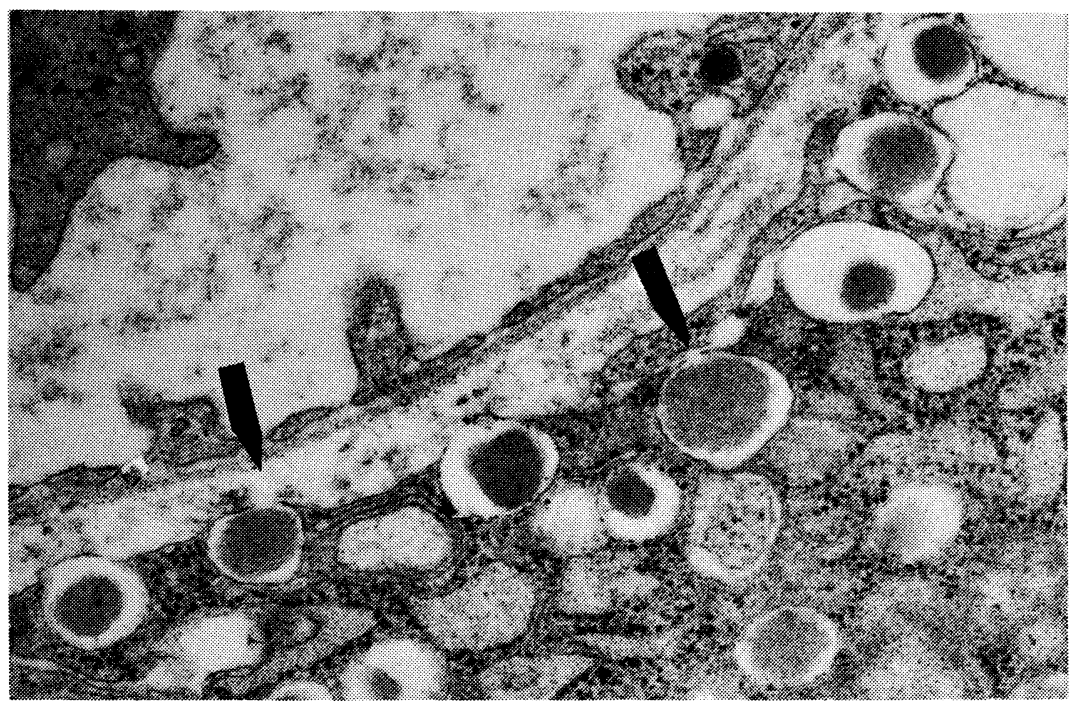

Fig. 10. Electron micrograph of pancreatic B cell of hypothalamic lesion rat at 10 weeks after the operation. Arrows indicate emiocytosis of secretory granules. ( $\times 36000)$

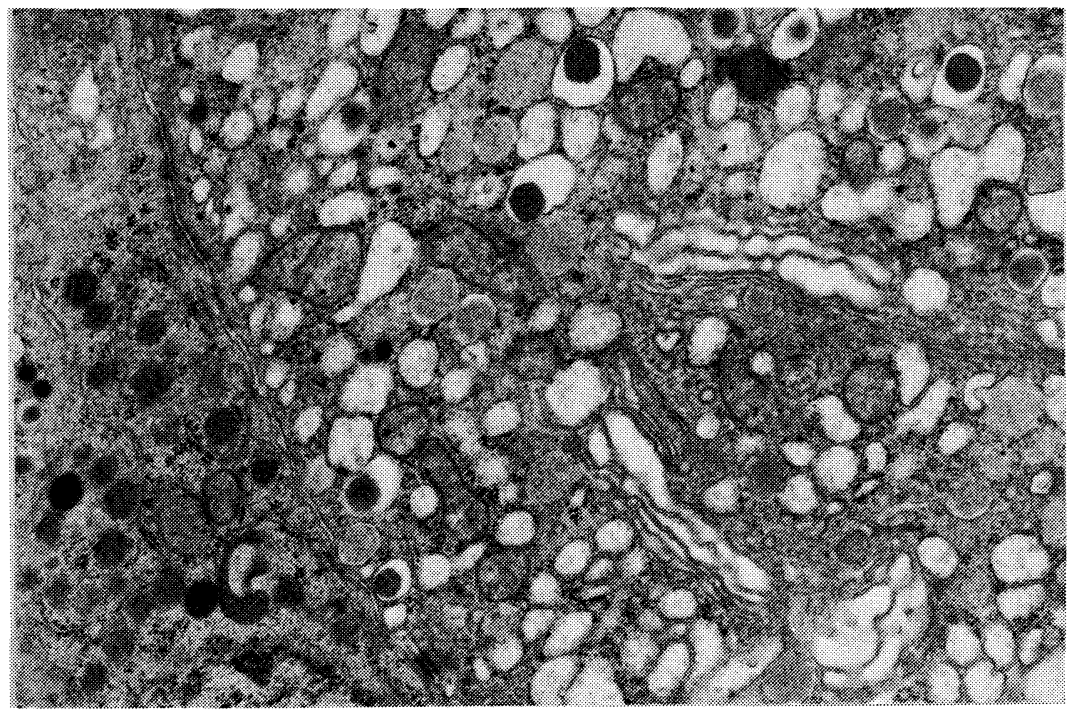

Fig. 11. Electron micrograph of pancreatic B cell of hypothalamic lesion rat at 10 weeks after the operation. Golgi apparatus are well developed. (X20000)

10週目の H T Lラットの荤ラ氏島 B 細胞の電顕像を Figs. 8〜12に示した．核は対照に比べてや、不正な ものが多かったが，核質，核小体には対照と大きい差異はなかった，細胞中の $\beta$ 顆粒は著明に減少し，残存 した顆粒では对照に比べて電子密度が高く, 小さいものが多かった（Fig. 8 ). 


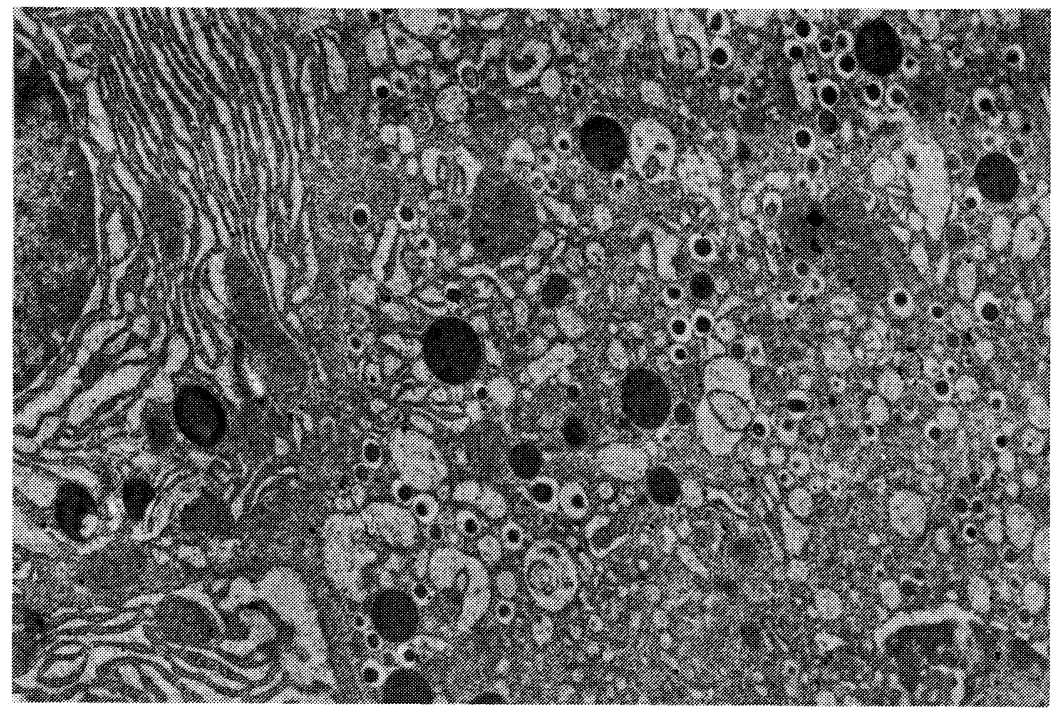

Fig. 12. Electron micrograph of mixed cell of hypothalamic lesion rat at 10 weeks after the operation. The cell contains B and zymogen granules in cytoplasm. (X12000)

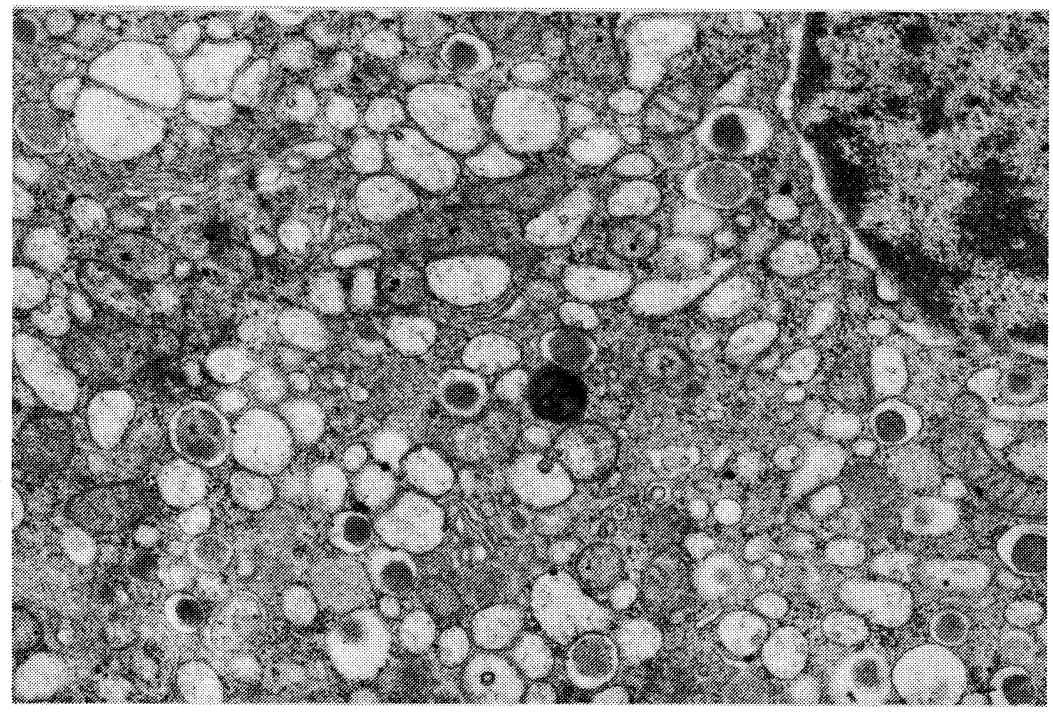

Fig. 13. Electron micrograph of pancreatic $B$ cell of hypothalamic lesion rat at 5 weeks after the operation. $(\times 12000)$

細胞によっては比較的顆粒の多いものもみられたが,このような細胞では顆粒の電子密度は低かった。ま た，顆粒には不整形のものが多く出現し限界膜の突起様突出や限界膜相互の融合なども認められた（Fig. 9). また，顆粒内容を失った空胞状構造にもしばしば遭遇した（Fig. 11）. 


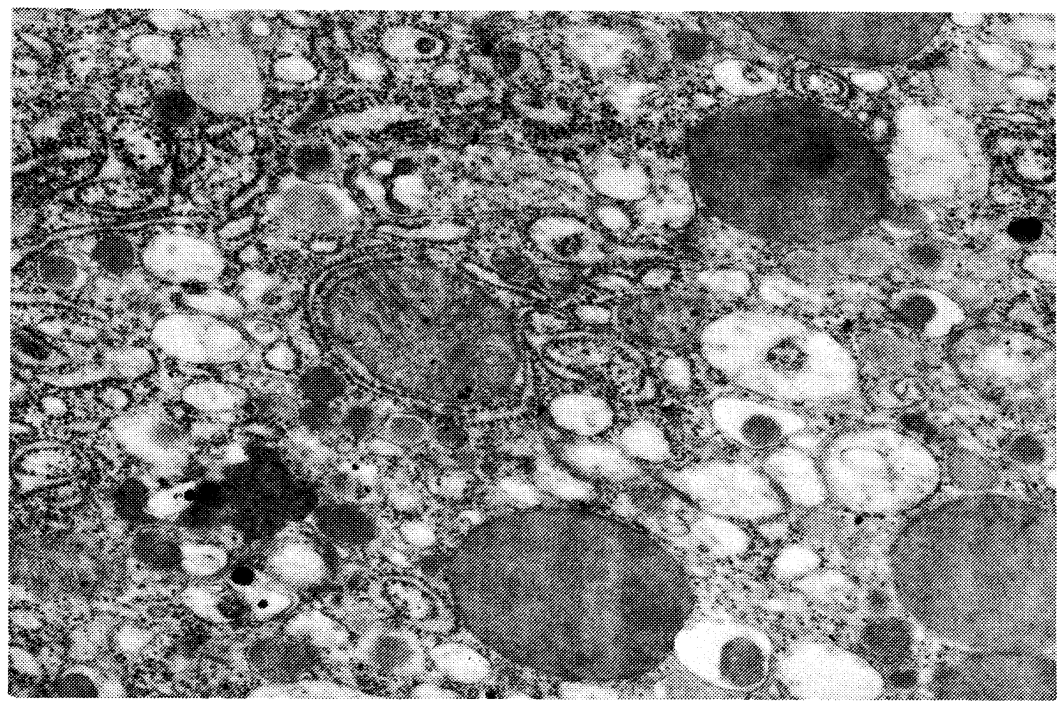

Fig. 14. Electron micrograph of mixed cell of hypothalamic lesion rat at 5 weeks after the operation. $(\times 24000)$

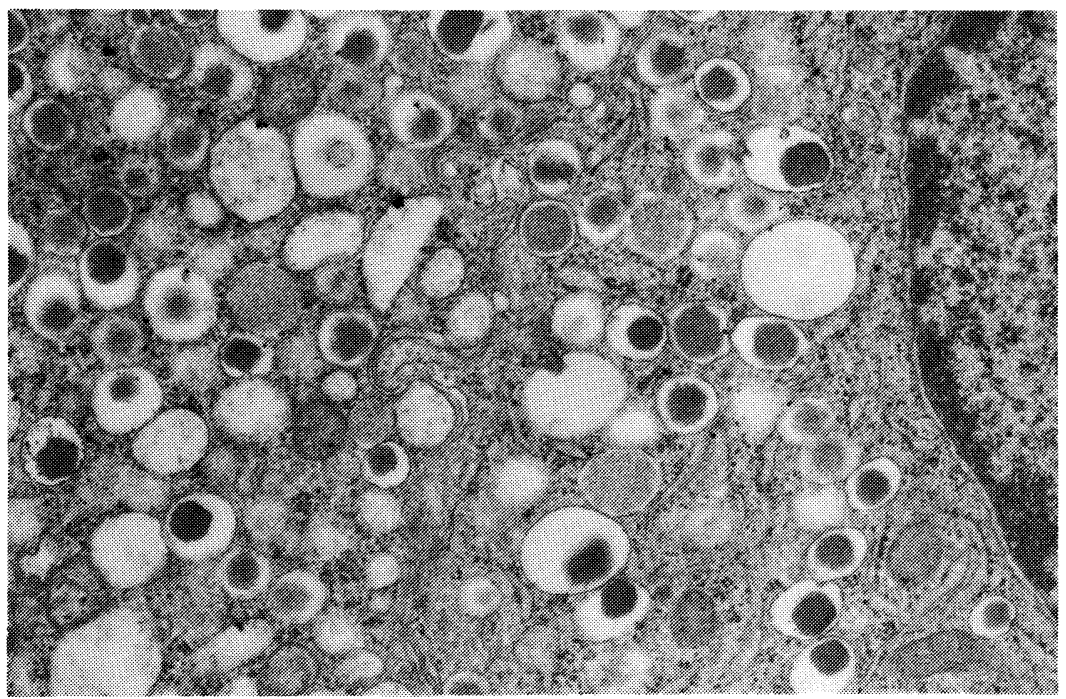

Fig. 15. Electron micrograph of $B$ cell of hypothalamic lesion rat at 1 week after the operation. $(\times 20000)$

原形質膜直下では顆粒限界膜は原形質膜に接着融合し，一部では周囲腔に開口する像がみられた (Fig. 10). これは開口分泌と考えられる像で，対照ラットに比べて多く認められた。

Golgi 装置はH T Lラットでよく発達していた。䧶状構造はしばしば著明に拡大し，その末端部が球状に 膨大し，その中に電子密度の低い物質が含まれていることがあった（Fig. 11）。粗面小胞体も対照に比べて よく発達しており, 粗面小胞体の一部は断裂し, 小胞状を呈していたが, 渦状を示すものはみられなかった。 
遊離の ribosome 毛特に増加していなかった（Fig. 8)。系粒体はや、膨化し, 円形状を呈し, cristaeの配 列にも乱れが認められ，数も対照に比して多かった（Fig. 8).

H T Lラットの荤ラ氏島周辺部では外分泌顆粒と内分泌顆粒の 2 種類を含むいわゆる mixed cell がみら れた。これらの細胞は外分泌顆粒の多い外分泌細胞に近い形態のものと, 内分泌顆粒が多く内分泌細胞に近 い形態のもの（Fig. 12）との 2 種類に分けられた。また，この外分泌顆粒は他の外分泌細胞のそれとの間に 著しい差を認めなかったが，内分泌顆粒（ $\beta$ 顆粒）はや、小さく顆粒の電子密度は高いものが多かった.

15週目の H T LラットのB 細胞の電顕像所見においても, 脱顆粒, pale granuleの増加, Golgi 装置およ び粗面小胞体の発達, mixed cell の出現などが観察された。これらの所見は, 10週目のラットとほぼ同様で あった。

つぎに 5 週目のH T LラットのB 細胞においては (Fig. 13), 脱顆粒, pale granuleの増加, Golgi 装置 および粗面小胞体の発達がみられた。脱顆粒, pale granuleの増加の程度は10週目のH T Lラットとほぼ同 じであったが, Golgi 装置および粗面小胞体の発達は10週目のそれに比べて弱い傾向がみられた。また, mixed cell はこの時期にも認められ, 外分泌顆粒が多い外分泌細胞に近い型のものが主であった（Fig. 14）.

H T L 後早期である 1 週目のラットのB 細胞においても（Fig. 15)，対照ラットに比べて脱顆粒の傾向が みられた。しかし，その程度は第 5，10週目のH T Lラットに比べると軽度であった. pale granule の増 加, Golgi 装置および粗面小胞体の発達は明らかでなく，対照ラットに比べて著明な差を認めなかった。糸 粒体にもほとんど変化はみられなかった. mixed cell はこの時期には認められなかった。

\section{成績の総括と考察}

視床下部（両側腹内側核領域）破壊ラットを作製し，体重，肥満度，血糖および血漿 I R I を経週的に測 定し，あわせて各時期における荤ラ氏島の組織学的変化を光顕と電顕とで観察した。

H T Lラットは術後早期から過食を示し, 体重増加も著しく, 術後10週には体重, Lee’s indexおよび体 脂肪量などからみて明らかな肥満となった。

これまでH T Lラットにおける肥満の成因は，視床下部の攝食中枢の障害による過食によるとされ，その 際に認められる代謝異常は二次的なものとされてきた ${ }^{(18)}$ しかし，鈴木 ${ }^{(39)}$ Han, Liu ${ }^{(13)}$ は, H T Lラットの食 事量, 掑食形態を対照と一致させても肥満が発生することを報告しており, 過食が肥満の唯一の原因ではな いと考えられる.

下垂体ホルモン，とくに成長ホルモンの低下もその成因として考之られたが，(6) 下垂体摘出を行なっても， ${ }^{(12)}$ G H を投与しても ${ }^{(9)}$ H T Lによって肥満が発現することから，下垂体ホルモンの分泌低下が肥満発生の主因 をなすものではないと思われる。

H T L 肥満ラットにおいて, 高インスリン血症がみられることは, Hales, Kennedy ${ }^{(11)}$ 以来知られている。 本実験においてもH T Lラットの血糖値は対照ラットと差を示さなかったが, 血漿 I R I 值はH T L 後, 比 較的早期から上昇し, 術後10週目に頂值に達し, どの時期においても対照ラットに比べて有意に高値を示し た。 あらかじめ膵ラ氏島を外科的手術または Alloxanなどで損傷し，インスリン分泌を抑えておくと H T L による肥満の発生が妨げられることも報告されており), 肥満と高インスリン血症との間には密接な関係がある と考えられる.

H T Lラットにおいて, 荤ラ氏島の拡大がみられることは Kennedy, Parker, ${ }^{(19)}$ Han $ら^{(14)}$ も簡単に述べ ている．著者の今回の実験において，H T L 後早期から脺ラ氏島の拡大を認めたが，この拡大は各細胞の肥 大よりも，むしろB 細胞を主とする細胞数の増加によることが認められた。この脺ラ氏島の拡大は, 血漿 I R I 值の変動とほぼ平行しており, 肥満の程度および血漿 I R I 值の上昇と一致していた.

H T Lラットにおける高インスリン血症や䡃ラ氏島の拡大の原因として, 第一に過食があげられる。しか 
し, Han ら ${ }^{(14)}$ は下垂体摘除あるいは pair fed を行なってもH T Lラットでは高インスリン血症や荤ラ氏島 の拡大がみられたことを報告しており，H T Lラットにおけるインスリン分泌の充進を過食や下垂体障害の みでは説明できない。

第二に vagus を介する神経性の因子が考えられる。葛谷, ${ }^{(25)}$ 栗谷 ${ }^{(21)}$ は兔の視床下部を電気刺激し, 腹内側部 （b-交感帯）はインスリン分泌抑制的に働き, 外側部（c-副交感帯）は分泌促進的に働くと報告し, Kanet○ら ${ }^{(17)}$ は犬のvagus を刺激し，インスリン分泌が増加することを確認している．著者の行なった破壊の部位 は黒津, ${ }^{(23)}$ 伴 ${ }^{(2)} の い j b-$ 交感帯に相当する部位で, この部位の破壊により副交感優位 (vagotony ) の状態と なり, vagus を介して䐙ラ氏島の拡大やインスリン分泌の立進が起こると考えられる。 ${ }^{(30)}$

第三にインスリン抵抗性の増大があげられる. 肥満の際に fat cell size の増大 ${ }^{(36)}$ や血中脂質の増大 ${ }^{(7)}$ が 認められこれらは insulin antagonistとして作用するといわれている，H T Lラットにおいて血漿 FFA，

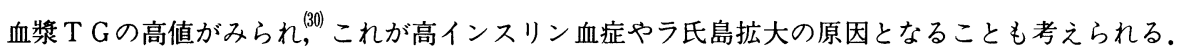

遺伝性肥満動物における荤の組織学的検討に関する報告は数多くみられるが, 視床下部破壊ラットにおけ る䐙組織像に関する報告は, Kennedy, Parker ${ }^{(19)}$ の光顕的研究がみられるにすぎず, 電顕的検討および高イ ンスリン血症との対比について検討した報告はみられない.

H T L ラットの荤ラ氏島のB 細胞では, 脱顆粒が光顕的にも電顕的にも認められた.このB 細胞の脱顆粒 像は, Zucker rat ${ }^{(38)}$ やyellow KK mice防においてもみられており, tolbutamide, ${ }^{(44)}$ cortisone, ${ }^{(40)}$ pilocarpine ${ }^{(41)}$ などの薬物投与時にも同様に認められている. 今回のH T Lラットにおいても高インスリン血 症に一致した時期に脱顆粒像が多くみられた。これらのことから，H T Lラットにおける脱顆粒所見も, 顆 粒分泌の充進の表現と考えられた。また経時的にみるとこの脱顆粒は 1 週目でもみられるが，5〜10週目が 著明であり，その程度は血漿 I R I の上昇と一致していた。

Golgi 装置, 粗面小胞体は分泌顆粒の合成および貯蔵の場と考之られている. 渡 ${ }^{(43)}$ はB 細胞の顆粒形成に ついて, 粗面小胞体のリボソームが, 核からのメッセンジャーR N Aの指令により分泌物を形成し, 粗面小 胞体の槽内に貯留し，これが buddingによりGolgi 装置に運ばれて濃縮され，分泌顆粒になると述べている。 H T Lラットにおいては, Golgi 装置および粗面小胞体は, 対照ラットに比べてよく発達し, その発達の程 度は脱顆粒の程度に伴って認められた。このような所見はZucker rat, ${ }^{(38)}$ sand rat, ${ }^{(26)}$ Chinese hamstar ${ }^{(28)}$ や alloxan, pilocarpine ${ }^{(41)}$ 投与時にもみられている.このように Golgi 装置, 粗面小胞体の発達は分 泌顆粒の合成, 貯蔵が進んでいることを示し, H T Lラットにおいても分泌充進に伴って合成, 貯蔵が起こ っていると推測された。

H T L ラットでは, 荤ラ氏島の周辺において 1 個の細胞内に内分泌顆粒と外分泌顆粒を含む細胞が多くみ

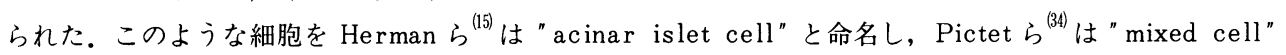
または” intermediate cell”と呼び Spiny miceにおいて,これらの細胞を" exocrineendocrine A," "exocrine-endocrine B", "exocrine-endocrin A and B" および" endocrine A and B"の各型に分けて いる.

著者のH T Lラットにみられた mixed cell は, Pictetらのいう"exocrine-endocrine B" type に相当 するものと考えられた。これらの細胞の出現の原因として, Mikami, Mutoh ${ }^{(31)}$ は外分泌細胞と内分泌細胞 が融合したものではないかと述べている. Pictet ${ }^{(34)} ら$, Shino, Iwatsuka ${ }^{(37)}$ は内分泌細胞の hyperplasia が刺激となり, 外分泌細胞が内分泌細胞に移行したためではないかと推察している. 著者の H T Lラットに おいても, 血漿 I R I 值が上昇するに従って, mixed cell がラ氏島周辺に多く認められた. 前述のごとく, 本ラットでは主に細胞数の増加によるラ氏島の拡大がみられたこととも考之合わせると，インスリンの合成， 貯蔵, 分泌が充進したために，外分泌細胞に何らかの刺激が加わり，内分泌細胞に移行したものと思われた。

B 細胞の顆粒分泌は，主に漏出分泌（diacrine）と開口分泌（emiocytosis）の 2 様式が考えられている. 
漏出分泌は, Kurosumi ${ }^{(22)}$ のV 型放出様式に相当するもので, Watari ${ }^{42)}$ らはブリの荤ラ氏島で B 細胞の顆 粒の core が細胞内で溶解して細胞外に漏出したものが $\mathrm{C}_{1}$, 細胞に相当するとしている.

H T Lラットにおいては，細胞膜に沿って内容の抜けた顆粒と思われるものが対照に比して多くみられた が，これが漏出分泌によるものであるかどうかは明らかでない。第二の開口分泌は Kurosumi のVI型放出様 式に相当し, Watari ら ${ }^{(2)}$ はブリの捇ラ氏島 B 細胞において六角結晶状の core をそのまま放出している像を とらえている。 今回著者の作製した H T Lラットにおいても開口分泌を思わせる像が認められ，対照に比し て多くみられた。

系粒体については, yellow KK mice, ${ }^{(37)}$ mutant mice ${ }^{(27)}$ などに扔いてその数の増加, 拡大あるいは変形 などが報告されている，本肥満ラットにおいても，インスリン分泌が立進する時期において，数や大きさの 增大および変形などがみられた。これらの変化もやはり, 細胞機能の充進に伴う一所見と思われる.

以上述べたごとく H T Lラットに打いては，著明な高インスリン血症がみられ，それにほぼ平行する䐙ラ 氏島の拡大が認められた。またこの拡大と体重，Lee’s indexおよび血漿 I R I 值との間にそれぞれ有意の 正相関を認めた。B細胞の微細構造所見では, 脱顆粒, Golgi 装置および粗面小胞体の発達, pale granule の増加, mixed cell の出現などが観察され，また顆粒の分泌については開口分泌を思わせる像が得られた。

これらの䐙ラ氏島の変化の成因としては, 前述のごとく視床下部一vagus一腪を介する自津神経系の影響 が考えられる。坂上 ${ }^{(35)}$ は鬼の視床下部を電気刺激し, 胼ラ氏島の微細構造の変化を観察し, $c-$ 副交感帯刺 激により $\beta$ 顆粒の分泌充進像が, b- 交感带刺激により $\beta$ 顆粒の合成促進像が認められることを報告してい る。しかし，増田 ${ }^{(30)}$ はvagotmy を行なったH T Lラットにおいても高インスリン血症がみられると述べてお リ，vagus を介する経路以外の因子も考えなければならない。

\section{結 語}

H T Lラットにおける肥満と高インスリン血症の成因を追求するために, H T L 後経時的に体重, 血糖, 血漿 I R I の測定とともに膵う氏島の組織学的検索を行ない，高インスリン血症と䐙ラ氏島との関係につい て検討した。

1.H T Lラットにおいては, 肥満と血漿 I R I 值の上昇がみられ, それにほぼ平行して腪ラ氏島の拡大 がみられた。また，このラ氏島の拡大は体重，肥満度および血漿 I R I 值と有意の正相関を示した。

2. H T Lラットの腪ラ氏島 B 細胞では, 対照ラットに比べて著明な脱顆粒, Golgi 装置および粗面小胞 体の発達, pale granule の増加がみられた。

3. H T Lラットの种ラ氏島周辺には多数の mixed cell が認められた。

4. H T Lラットの荤ラ氏島 B 細胞では，開口分泌を思わせる像が対照に比して多くみられた。

以上H T Lラットにおける膵ラ氏島の組織学的変化は本肥満のインスリンの分泌充進をよく反映している と思われる。

本論文の要旨は, 第48回日本内分泌学会総会（1975年京都）で発表した。御指導, 御校閲を受けた森博愛 教授, 近森一正講師拉よび本学第 2 解剖大黒成夫教授に深謝します。また, 本研究に御協力を受けた第 2 内 科学教室員各位にも感謝します。

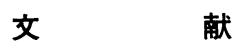

1) Anand, B.K. and Brobeck, J.R.: Hypothalamic control of food intake. Yale J. Biol. Med., 24：123-139，1951. 2) 伴 忠康：視床下部の線維連絡, 神経進歩 10: 77-83, 1966. 3) Brobeck, J.R., Tepperman, J. and Long, G.N.H.: Experimental hy- 
pothalamic hyperphagia in albino rat. Yale J. Biol. Med., 15: 831-853, 1943.

4) Brecher, G. and Waxler, S.H.: Obesity in albino rat due to single injections of gold thioglucose. Proc. Soc. Exper. Med., 70: 498-501, 1949.

5) 近森一正：視床下部性肥満の 脂質動員に関する研究, 四国医誌, 25：608-621， 1969.

6) Frohman, L.A. and Bernardis, L.L.: Growth hormone and insulin levels in weanling rats with ventromedial hypothalamic lesions. Endocrinology, 82: 1125-1132, $1968 . \quad 7)$ Frohman, L.A., Bernardis, L.L., Schnatz, J.D. and Burek, L.: Plasma insulin and triglyceride levels after hypothalamic lesions in weanling rats. Am. J. Physiol., 216: 1496-1501, 1969.

8) Frohman, L.A. and Bernardis, L.L.: Effect of hypothalamic lesions at different loci on development of hyperinsu linemia and obesity in the weanling rat. J. Comp. Neurol., 141: 107-116, 1971.

9) Goldman, J.K., Schnatz, J.D., Bernardis, L.L. and Frohman, L.A.: Adipose tissue metabolism of weanling rats after destruction of ventromedial hypothalamic nuclei: effect of hypophysectomy and growth hormone. Metabolism, 19: 9951005, 1970.

10) Gomori, G.: Aldehyde-fuchsin: new stain for elastic tissue. Am. J. Clin. Pathol., 20: 665-667, $1950 . \quad 11)$ Hales, C.N. and Kennedy, G.C.: Plasma glucose, non-esterified fatty acid and insulin concentrations in hypothalamic-hyperphagic

rats. Biochem. J., 90: 620-624, 1964. 垂体の影響, 四国医誌, 30: 228-243，1974.

and impaired growth of rats force fed 40 days after hypothamic lesions. Am. J. Physiol. 211: 229-231, 1966.

14) Han, P.W., Yu, Y.K. and Chow, S.L.: Enlarged pancreatic islets of tube-fed hypophysectomized rats bearing hypothalamic lesions. Am. J. Physiol. 218: 769-771, 1970.

15) Herman, L., Sato, T. and Fitzgerald, P.J.: Electron microscopy of "acinar-islet" cells in the rat pancreas. Fed. Proc., 22: 603, 1963.

16) Hetherington, A.W. and Ranson, S.W.: Hypothalamic lesion and other phenomena in the rat. Anat. Rec., 78: 149-172, 1940.

17) Kaneto, A., Kosaka, K. and Nakao, K.: Effects of stimulation of the vagus nerve on insulin secretion. Endocrinology, 80: 530-536, 1967.

18) Kennedy, G.C. and Mitra, J.: Hypothalamic control of energy balance and the reproductive cycle in the rats. Physiologist, 166: 395-407, 1963.

19) Kennedy, G.C. and Parker, R.A.: The islets of Langerhans in rats with hypothalamic obesity. Lancet, 2: 981-982, $1963 . \quad 20)$ 北村元仕, 三上晴子, 有松芳子：グルコースオキ シダーゼを用いた血液ブドウ糖定量法, 臨検, 6: 585-590, 1962.

の膵島細胞に及ぼす影響に就て, 大阪大医誌, 7：217-235, 1955 .

21) 栗谷種一：自律中枢

22) Kurosumi, K.:

Electron microscopic analysis of the secretion mechanism. Int. Rev. Cytol., 11: 1-124, 1961. 23) 黒津敏行：自律中枢に関する実験的組織学的研究, 第12回日本医学会会誌, 99$108,1947$. 24) 桑田勝夫：視床下部性肥満における脂肪組織脂酸構成の変化, 四国医誌, 26: 524-536, 1970.

25) 葛谷 健：膵内分泌の中枢調節に関する研究, 第 2 報, 視床下部の刺激, 破壊または下垂体剔除の insulin 分泌に及ぼす影響, 日内会誌, 51: 1049-1058, 1962.

26) Like, A.A. and Miki, E.: Diabetic syndrome in sand rats. IV morphologic changes in islet tissue. Diabetologia, 3: 143-166, 1967.

27) Like, A.A. and Chick, W.L.: Studies in the diabetic mutant mouse: electron microscopy of pancreatic islets. Diabetologia, 
6: $216-242,1970$.

28) Like, A.A., Gerritsen, G.C., Dulin, W.E. and Gaudreau, P.: Studies in the diabetic Chinese hamster: electron microscopy of pancreatic islets. Diabetologia, 10: 509-520, $1974 . \quad 29)$ Luft, J.H.: Improvements in epoxy resin embedding methods. J. Biophys. Biochem. Cytol., 9: 409-414, $1961 . \quad 30)$ 増田和代 : 視床下 部性肥満のラットにおける血漿 insulin および triglyceride の変動一迷走神経切断の影響, 四国医誌, 31: 1-12, $1974 . \quad 31)$ Mikami, S. and Mutoh, K.: Light- and electron-microscopic studies of the pancreatic islet cells in the chicken under normal and experimental conditions. Z. Zellforsch, 116: 205-227, $1971 . \quad 32)$ Morgan, C.R. and Lazarow, A.: Immunoassay of insulin: two antibody system plasma insulin levels of normal, subdiabetic and diabetic rats. Diabetes, 12: 115-126, 1963.33$)$ 大村 裕, 国吉 真: 捸食の中枢機構, 生 体の科学, 15: 168-190, $1964 . \quad 34)$ Pictet, R., Orci, L., Gonet, A.E., Rouiller, C. and Renold, A.E.: Ultrastructural studies of the hyperplastic islets of Langerhans of spiny mice (Acomys Cahirinus) before and during the development of hyperglycemia. Diabetlogia, 3: 188-211, 1967. 35）坂上正義：視床下部の電気刺激による朠臓ランゲルハンス島 $\mathrm{B}$ 細胞 の微細構造の変化と自律神経終末について, 解剖誌, 47: 154-171, 1972.

36) Salans, L.B., Knittle, J.L. and Hirsch, J.: The role of adipose cell and adipose tissue insulin sensitivity in the carbohydrate intolerance of human obesity. J. Clin. Invest., 47: 154-171, 1972. 37) Shino, A. and Iwatsuka, H.: Morphological observations on ' pancreatic islets of spontaneous diabetic mice "yellow KK". Endocrinol. Jap., 17: 459-476, $1970 . \quad 38)$ Shino, A., Matsuo, T., Iwatsuka, H. and Suzuki, Z.: Structural changes of pancreatic islets in genetically obese rats. Diabetologia, 9: 413-421, 1973.

39）鈴木英司：視床下部性肥満の体構成に関する研究，四国医誌，26: 574-586, 1970.

40) Volk, B.W. and Lazarus, S.S.: Ultramicroscopic studies of rabbit pancreas during cortisone treatment. Diabetes, 12:162-173, 1963.41$)$ 渡 仲三:2・3の実験条件 下における腪島の超微形態学, 特に B 細肥の変化について, 日内分泌会誌, 44: 721-727, 1959.

42) Watari, N., Tsukagoshi, N. and Honma, Y.: The correlative light and electron microscopy of the islets of Langerhans in some lower vertebrates. Arch. Histol. Jap., 31: 371$392,1970$.

43) 渡 仲三：腪臟ランゲルハンス島の微細構造と機能, 細胞, 3: 12-23, 1971.

44) Williamson, J.R., Lacy, P.E. and Grisham, J.W.: Ultrastructural changes in islets of the rat produced by tolbutamide. Diabetes, 10:460-469, 1961.

45) 安岡 劭：視床下部障害に上る肥満の脳の組織学的研究, 四国医誌, 26: 231-245, 1966.

46) 安岡 恒, 油谷友三: 視床下部性肥満の研究（第 4 報), 日内会誌, 58: 1028-1029, 1969.

47) Young, T.K. and Liu, A.C.: Hyperphagia, insulin and obesity. Chinese J. Physiol., 19: 247-253, 1965. 